\title{
Discovery of an Escape Tunnel in Sobibor
}

\author{
Ivar Schute*, Wojchiech Mazurek and Yoram Haimi \\ Department of Archaeology, Israel
}

Submission: July 08, 2018; Published: August 01, 2018

*Corresponding author: Ivar Schute, Department of Archaeology, Israel, Email: i.schute@raap.nl

\section{Abstract}

In 2013 during excavations in the former Nazi-extermination camp in Sobibor, in nowadays eastern Poland, an escape tunnel was discovered. It became clear the tunnel leads from the barrack of the Sonderkommando, besides the gas chambers, outside camp III, the area with the gas chambers. In the autumn of 1943 the inmates tried to escape, but the tunnel was discovered. All members of the Sonderkommando were executed, as very few testimonies confirmed.

Keywords: Escape Tunnel; Gas chambers; Lagers; Excavations; Monument; Traces; Labourers; Jewish community; Terrible conditions; Fenced path; knitting

\section{Introduction}

The archaeological excavations in the former Naziextermination camp of Sobibor in eastern Poland are made possible by a collaboration of four countries: Israel, Netherlands, Poland and Slovakia. Main goal of this joint project is the realization of a visitor centre and monument on the site. The still ongoing excavations, upscaled since 2011, are carried out in order to make construction works possible, and to reveal sensible traces, gain knowledge about the inner structure of the camp and to secure personal items. The excavations were carried out under supervision of Wojciech Mazurek MA (Sub Terra Archaeological Research, Chełm, Poland), Yoram Haimi (representative of Yad Vashem, Israel) and Ivar Schute (representative of the Dutch Ministry of Welfare, since 2013).

\section{Inner Structure of the Camp}

The former Nazi-extermination camp of Sobibor, in which around 200,000 Jewish people were killed in 1942-1943, consisted of a few different Lagers, or camps. Alongside the still existing railway tracks the so-called Vorlager was situated, where the SS-troops had their quarters. Victims coming with trains, arrived at the ramp and were forced to go to camp II. In these barracks their belongings and clothes were taken by forced labourers, housing in camp I, behind the Vorlager. Naked, the victims were forced into a long fenced path, the Himmelfahrtstrasse, which ended in camp III, the area with gas chambers and mass graves. The bodies had to be 'processed' by another group of forced labourers, the Sonderkommando, who lived under terrible conditions in one or two barracks inside camp III. At the 14th of October of 1943 the labourers in camp
I revolted. About 300 of them escaped of which 50 survived the war. The extermination camp was broken down by the Germans. Nowadays nothing rests, only archaeological traces. During the excavations an earlier escape tunnel was discovered, leading from the barrack of the Sonderkommando outside the fences of camp III. This tunnel was partly excavated after discovery in 2013 and later on, in 2016 [1,2].

\section{The Results of the Excavations}

In 2013 a barrack was found and excavated just east of an asphalt square, under which, as became clear the next year, the foundations of the gas chambers were still preserved. The barrack lies within a fenced area and housed the members of the Sonderkommando within camp III. A surprising discovery were the traces of an escape tunnel, at a depth of about $1.60 \mathrm{~m}$ below the floor of the barrack. It leads in a easterly direction under the fences that surrounded camp III. Partly it was excavated in 2013 and 2016. The eastern end of the tunnel is still visible in the forest as a small ditch, the result of collapsing or destruction. Following this ditch it became clear the tunnel reaches outside camp III, with a length of an estimated $20 \mathrm{~m}$. Due to the sandy soil present in Sobibor, the Jewish prisoners who dug the escape channel supported it with wooden beams. In the tunnel little personal items were found; a $1.5 \mathrm{~m}$ long metal rod was apparantly used to dig [3].

\section{Historical References}

Very few historical references stated that the members of the Sonderkommando were killed after discovery of an escape tunnel. As an example may serve the testimony of an 
unnamed girl from Holland. At age seventeen this young woman worked with a group of women prisoners knitting clothing. She described the discovery of an escape tunnel by the Nazis prior to its completion. In wake of the discovery of the tunnel, all the prisoners of Camp III were summarily executed.

\section{Comparison}

In 2016 at the killing site of Ponar (nowadays Paneriai), just outside Vilnius, the capital site of Lithuania another escape tunnel was revealed using geophysicla techniques. Scientists of The United States, Canada, Israel and Lithuania were able to locate the $34 \mathrm{~m}$ long tunnel, which was already known from historical records. Futhermore, the beginning of the tunnel was already discovered in 2004. In Ponar about 100,000 people were killed, 70,000 of them of Jewish origin. Also at this site the Germans, towards the end of the war, tried to erase their traces. Prisoners from the Stutthof camp (nowadays Poland) were transported to Ponar to excavate the mass graves and and burn the bodies. At night, these prisoners had to stay in one of the pits used in the killings. It were these prisoners who dug the tunnel in aboit three months under frightful circumstances. Forty of them escaped on the $15^{\text {th }}$ of April, 1944. Eleven of them survived and gave testimony.

Another parallel (amongst the very few) is the dunnel dug out of the Novogroduk ghetto, in 1943 a partly Jewish Polish city, nowadays a city in Belarus: Navahradak. About 350 persons escaped through the tunnel which appeared to have a length of about $200 \mathrm{~m}$, starting out of a barrack, comparable to the Sobibor tunnel. Societal meaning

Although the results of the Sobibor and Ponar researches still have to be analyzed and published, it becomes clear that these tunnel especially amongst the Jewish community have a great societal meaning. They form a clear example of Jewish resistance, under the most horrible circumstances one can imagine. As Markas Zingeris, director of the Vilna Gaon Jewish State Museum in Vilnius, stated after the geophysical mapping of the Ponar tunnel: 'It is a very important discovery, because this is another proof of resistance of those who were about to die.'

\section{References}

1. Haimi Y (2015) Preliminary Report of Archaeological Excavations in the Sobibór Extermination Center. Fundacja Polsko-Niemieckie Podjednanie, Warsaw, Poland.

2. Haimi Y (2016) Preliminary Report of Archaeological Excavations in the Sobibór Extermination Center. Fundacja Polsko-Niemieckie Podjednanie, Warsaw, Poland.

3. Mazurek T, Mazurek M, Ratajczak R (2016) The resulats of the preinvestment archaeological research conducted on the site of the former Nazi-German Extermination Camp in Sobibor. Sub Terra Archaeological Research, Chełm, Poland.

\section{Your next submission with Juniper Publishers will reach you the below assets}

- Quality Editorial service

- Swift Peer Review

- Reprints availability

- E-prints Service

- Manuscript Podcast for convenient understanding

- Global attainment for your research

- Manuscript accessibility in different formats

( Pdf, E-pub, Full Text, Audio)

- Unceasing customer service

Track the below URL for one-step submission

https://juniperpublishers.com/online-submission.php 